\title{
Field Evaluation of BRRI USG Applicator in Dry and Wet Season of Rice Cultivation
}

\author{
M A Hossen ${ }^{1 *}$, M A Rahman ${ }^{1}$, M K Zaman ${ }^{1}$ and M M Islam ${ }^{1}$
}

\begin{abstract}
BRRI (Bangladesh Rice Research Institute) USG (Urea super granule) applicator was developed to apply USG in non-oxidized zone at 6-10 $\mathrm{cm}$ depth from surface at desired spacing to maintain the recommended USG fertilizer doses of 118 and $168 \mathrm{~kg} \mathrm{ha}^{-1}$ during Aman and Boro season, respectively that could be maintained with the adjustment of the applicator for $20 \times 20 \mathrm{~cm}$ transplanting spacing. It was designed and fabricated with an adjustable facility for two rows operation in the rice field at spacing of $18 \times 20,20 \times 20$ and $22 \times 20 \mathrm{~cm}$. The modified USG applicator tested in the BRRI regional stations (RS) during Aman 2011 and the farmers' fields during Boro 2012 season. Walking speed directly influenced the field capacity of the applicator. Walking speed during field operation of the applicator depends on the soil type, USG placement time and puddled condition of the soil and it was varied $2.46-3.72 \mathrm{~km} \mathrm{hr}^{-1}$. Field capacity was observed 0.13 and $0.14 \mathrm{ha} \mathrm{hr}^{-1}$ during Boro and Aman season, respectively whereas manual USG application capacity was observed about $0.02 \mathrm{ha} \mathrm{hr}^{-1}$. The depth of USG placement by the applicator $(6.01-6.32 \mathrm{~cm})$ was found more compared to manual application $(5.61-5.75 \mathrm{~cm})$. The yield performance of USG plots was identical in all locations during both the seasons either applied by hand or by machine. However, in some cases, USG gave significantly higher grain yield compared to prilled urea applied by hand broadcasting method.Modified BRRI USG applicator saved urea fertilizer, ensured proper placement of USG in subsurface zone and reduced drudgery without sacrificing grain yield.
\end{abstract}

Key words: Field capacity, placement depth, grain yield

\section{INTRODUCTION}

Urea is one of the major essential elements of plant. The plant takes nutrient available in the root-zone as food for growth and increase of yield. The ultimate aim of applying fertilizer at the root-zone is to meetup the deficiency of the plant. Farmers of Bangladesh use urea as a source of nitrogen of which major portion is imported at the expense of hard earning foreign currency. In 2008-09, Bangladesh government imported 137.5 million tons of urea (BBS, 2015). The field efficiency of urea is very low and the main nitrogen loss processes are: Ammonia volatization, nitrification, denitrification, leaching and run off. Other important nitrogen transformations are biological immobilization, ammonia fixation by clay minerals, and soil organic matter. In this way loss of about 20$30 \%$ of the total applied fertilizer occurred
(Craswell and Vlek, 1979). The most attractive practice to a farmer in terms of application is to broadcast prilled urea on the top soil in which farmer can fertilize two hectares in one day. However, with the ever increasing demand of fertilizer, the practice of surface broadcasting is uneconomical and wasteful since $20 \%$ of the broadcast fertilizer is lost by ammonium volatilization alone in the surface water (De Datta, 1978).

On the other hand, the efficiency of granular urea is more than prilled urea. Moreover, farmers can get $20 \%$ more yield using granular urea (AIS, 2008). Deep placement of urea super granules in transplanted rice is an agro-nominally efficient and environmentally safe as compared with the traditional application method of prilled urea. The proper deep placement of USG decreases urea- $\mathrm{N}$ losses, improves $\mathrm{N}$ availability to rice plants and eventually helps to increase grain

${ }^{1}$ Farm Machinery and Postharvest Technology Division, BRRI, Gazipur. *Coresponding author's E-mail: ahossenbrri@gmail.com 
yields significantly, especially at $\mathrm{N}$ rates that small rice farmers can afford. Granular urea is to be placed at 8-10 $\mathrm{cm}$ deep at the center of four consecutive hills of two adjacent rows at 10-15 days after transplanting (Bhuiyan et al., 1998).

On the basis of size and weight, granular urea becomes different. A 90 milligram weight granule is known as urea super granule (USG). Three USG are used in one place for Boro rice and two for Aus and Aman rice. Another two types of USG granules (1.8 and $2.7 \mathrm{~g}$ ) are known as urea mega granule (UMG). For Aus and Aman rice cultivation, one USG of 1.8 and 2.7 $\mathrm{g}$ are used in one place respectively (Huda and Khan, 2014).

However, the deep placement of USG by hand after transplanting is a slow field operation thus requiring much labour. This labour intensiveness and drudgery of placing USG manually have seriously limited USG adoption by rice farmers in South and Southeast Asia (Savant et al., 1992). About 6-8 work day $\mathrm{ha}^{-1}$ is required for manual placement of USG in rice transplanted field. Hence, a mechanical device is necessary to improve the work efficiency of labour. Applicators of IFDC, IRRI and Chinese model have been tested at BRRI in 1998. All these are not found effective in the field and do not push the USG inside the soil surface. On the other hand, metering device and skidding mechanism do not work properly and leads to miss the pickup of USG from the hopper resulting missing placement in the field. BRRI designed and developed a push type manually operated USG applicator overcoming those problems (Hossen et al., 2013). Initially, the applicator was designed for $20 \times 20 \mathrm{~cm}$ spacing. The applicator was modified for 18,20 and $20 \mathrm{~cm}$ line to line spacing with adjustable mechanism (Hossen et al., 2013). Both models were evaluated only in BRRI research farm, Gazipur. Therefore, there is a need to evaluate the modified USG applicator in different locations. Therefore, the present study was undertaken to evaluate the modified BRRI USG applicator in the farmers' field and BRRI RS during the Boro and Aman seasons for large scale validation.

\section{OBJECTIVES}

The objectives of the study were to:

- Observe the field performance of the applicator using 1.8 and $2.7 \mathrm{~g}$ size granule during Aman and Boro season, respectively.

- Compare the yield performance with traditional application of prilled and USG fertilizer

\section{METHODOLOGY}

USG applicator was designed for two rows application of fertilizer in a single pass using AutoCAD drawing tools. According to the design, prototype was fabricated in the research workshop and tested in the laboratory and BRRI research fields. During the test, problems regarding USG dispensing efficiency, USG clogging, furrow opening and covering and depth of placement of USG were collected for further improvement of the applicator. After rectification of the problems, field trials were conducted in the farmers' field during Aman 2011 and Boro 2012 seasons.

\section{Performance test of the applicator}

BRRI USG applicator was tested using urea mega granules (2.7 gm size of USG) in both laboratory and field condition to observe the performance. During the test, following data were collected:

- $\quad$ USG dispensing efficiency (\%)

- Depth of placement (cm)

- Accuracy of placement between rows (\%)

- Walking speed $\left(\mathrm{km} \mathrm{hr}^{-1}\right)$

- $\quad$ Field capacity (ha hr-1)

\section{Applicator operation}

There are three options to adjust the spacing of the applicator considering the line to line distance of the transplanted rice. Two nuts of the main axle, four nuts of the frame and two nuts of the handle have to be adjusted among the three options of 18,20 or $22 \mathrm{~cm}$ considering the existing line spacing of the transplanted rice before field operation (Fig. 1). 


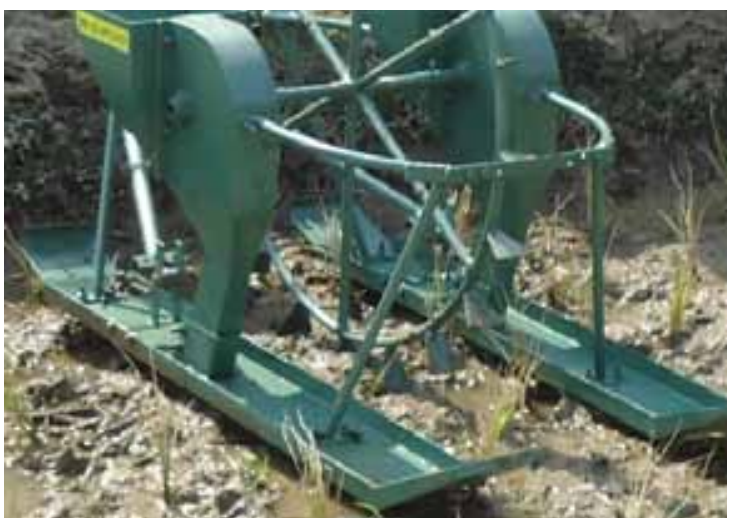

Fig. 1. Adjusting mechanism of the applicator with line spacing.

Handle height also have to be adjusted in such way that the operator feels comfort to operate the applicator and covering device remain in contact with the soil horizontally (Fig. 1). It is always operated by pushing force. During pulling, muddy soil blocked the dispensing channel and restricted the flow of granules.

Field trials of the USG applicator during Aman 2011 and Boro 2012

BRRI dhan49 was cultivated in all the regional stations and BRRI dhan33 was cultivated only in the farmer's field of Netrokona district in Aman season. BRRI dhan29 were cultivated in all the locations in Boro season. Thirty-five to 40-dayold seedlings were transplanted manually. In Both the seasons, $20 \times 20 \mathrm{~cm}$ spacing were maintained. Sizes of USG were $1.8 \mathrm{~g}$ (mega size) for Aman and $2.7 \mathrm{~g}$ (mega size) for Boro season. Table 1 and Table 2 present the general information of the experiments.

\section{Design}

The following treatments were arranged in a randomized complete block (RCB) design with three replications.

- $\mathrm{T}_{1}=$ USG application by USG applicator

- $\mathrm{T}_{2}=$ Manual application of USG

- $\mathrm{T}_{3}=$ Hand broadcasting of prilled urea

Fertilizer dose in terms of USG was same for $\mathrm{T}_{1}$ and $\mathrm{T}_{2}$. Prilled urea was broadcast in $\mathrm{T}_{3}$ by hand on the basis of BRRI recommended dose. Other fertilizer and management practices were the same for all treatments.

\section{Data were collected on}

- $\quad$ Time required to apply urea in the field (hr ha $^{-1}$ ) for all treatments

- Capacity of BRRI USG applicator and manual application of USG

- $\quad$ Plant height and tiller number at different days after transplanting

- $\quad$ Yield and yield components

\section{Location in Aman season}

Total number of six field trials was conducted in BRRI research farm, Gazipur and BRRI regional stations of Kushtia, Rajshahi, Rangpur, Comilla and one in farmer's field, Netrakona to observe the field performance of the applicator (Table 1).

\section{Location in Boro season}

Eleven field trials were conducted in different locations of the country during Boro 2011 season (Table 2). The locations were (i) Baria, sadar upazila, Kushtia (Kushtia-1), (ii) Tarapur,

Table 1. General information of the experimental plots, Aman 2011.

\begin{tabular}{|c|c|c|c|c|c|c|c|c|c|}
\hline \multirow{2}{*}{ Location } & \multicolumn{6}{|c|}{ Fertilizer rate $\left(\mathrm{kg} \mathrm{ha}^{-1}\right)$} & \multirow{2}{*}{$\mathrm{D} / \mathrm{T}$} & \multirow{2}{*}{$\begin{array}{c}\text { D/USG } \\
\text { App }\end{array}$} & \multirow{2}{*}{$\begin{array}{c}\text { Date of } \\
\text { harvesting }\end{array}$} \\
\hline & TSP & $\mathrm{MoP}$ & Gyp. & $\mathrm{ZnSO}_{4}$ & PU & USG & & & \\
\hline BRRI RS, Kushtia & 52 & 60 & 35 & 5 & 210.0 & 118.0 & $24 / 07 / 10$ & $03 / 08 / 10$ & $29 / 11 / 10$ \\
\hline BRRI RS, Rajshahi & 62 & 80 & 45 & 5 & 172.0 & 118.0 & $05 / 08 / 10$ & $16 / 08 / 10$ & $15 / 11 / 10$ \\
\hline BRRI, Gazipur & 76 & 90 & 45 & 5 & 172.0 & 118.0 & $10 / 08 / 10$ & $22 / 08 / 10$ & $25 / 11 / 10$ \\
\hline Purbadhala, Netrakona & 65 & 70 & 40 & 10 & 170.0 & 118.0 & $10 / 08 / 10$ & $23 / 08 / 10$ & $10 / 11 / 10$ \\
\hline BRRI RS, Comilla & 75 & 100 & 60 & 10 & 210.0 & 118.0 & $20 / 08 / 10$ & $30 / 08 / 10$ & $01 / 12 / 10$ \\
\hline BRRI RS, Rangpur & 80 & 100 & 60 & 10 & 175.0 & 118.0 & $14 / 08 / 10$ & $25 / 08 / 10$ & $30 / 11 / 10$ \\
\hline
\end{tabular}


Table 2. General information of the experimental plots, Boro 2012.

\begin{tabular}{|c|c|c|c|c|c|c|c|c|c|}
\hline \multirow{2}{*}{ Location } & \multicolumn{6}{|c|}{ Fertilizer rate $\left(\mathrm{kg} \mathrm{ha}^{-1}\right)$} & \multirow{2}{*}{$\mathrm{D} / \mathrm{T}$} & \multirow{2}{*}{$\begin{array}{l}\text { D/USG } \\
\text { App }\end{array}$} & \multirow{2}{*}{$\begin{array}{c}\text { Date of } \\
\text { harvesting }\end{array}$} \\
\hline & TSP & MoP & Gyp. & $\mathrm{ZnSO}_{4}$ & PU & USG & & & \\
\hline Kushtia-1 & 100 & 120 & 70 & 15 & 285 & 168 & $30 / 12 / 10$ & $10 / 01 / 10$ & $07 / 05 / 11$ \\
\hline Kushtia-2 & 100 & 120 & 70 & 15 & 285 & 168 & 04/01/11 & $11 / 01 / 11$ & $15 / 05 / 11$ \\
\hline Habiganj-1 & 90 & 100 & 60 & 12 & 280 & 168 & $10 / 01 / 11$ & $19 / 01 / 11$ & $15 / 05 / 11$ \\
\hline Habiganj-2 & 90 & 100 & 60 & 12 & 280 & 168 & $02 / 02 / 11$ & $14 / 02 / 11$ & 09/05/11 \\
\hline Habiganj-3 & 90 & 100 & 60 & 12 & 280 & 168 & $10 / 01 / 11$ & $20 / 01 / 11$ & $10 / 05 / 11$ \\
\hline Comilla-1 & 110 & 125 & 75 & 18 & 340 & 168 & $28 / 01 / 11$ & $15 / 02 / 11$ & $18 / 05 / 11$ \\
\hline Comilla-2 & 110 & 125 & 75 & 18 & 340 & 168 & $27 / 01 / 11$ & $09 / 02 / 11$ & $19 / 05 / 11$ \\
\hline Rangpur-1 & 100 & 120 & 65 & 15 & 280 & 168 & 24/01/11 & $06 / 02 / 11$ & $21 / 05 / 11$ \\
\hline Netrakona-1 & 100 & 120 & 70 & 15 & 285 & 168 & $13 / 01 / 11$ & $25 / 01 / 11$ & $27 / 05 / 11$ \\
\hline Netrakona-2 & 100 & 120 & 70 & 15 & 285 & 168 & 25/01/11 & $05 / 02 / 11$ & 01/05/11 \\
\hline Rajshahi-1 & 100 & 120 & 75 & 18 & 300 & 168 & $12 / 02 / 11$ & $24 / 02 / 11$ & $12 / 05 / 11$ \\
\hline
\end{tabular}

Note: 1 hectare $=247.16$ decimal, D/T=Date of transplanting, D/USG App.=Date of USG application and PU=Prilled urea, TSP-Tripple super phosphate, MoP-Murate of potash, Gyp.-Gypsum and $\mathrm{ZnSO}_{4}$-Zinc Sulphate.

Kumarkhali upazila, Kushtia (Kushtia-2), (iii) Richi, sadar upazila, Habiganj (Habiganj-1), (iv) Churango-rayer-para, Baniachang, Habiganj (Habiganj-2), (v) BRRI RS, Habiganj (Habiganj-3), (vi) Kharataiya, Burhichang upazila, Comilla (Comilla-1), (vii) Narpati, Laksam upazila, Comilla (Comilla-2), (viii) Akkelpur, sadar upazila, Rangpur (Rangpur-1), (ix) Challisha, sadar upazila, Netrokona (Netrokona-1), (x) Gohalakanda, Purbadhala upazila, Netrokona (Netrokona-2) and (xi) Khasba, Paba upazila, Rajshahi (Rajshahi-1).

\section{RESULTS}

As per design of the applicator, it was fabricated in the FMPHT research workshop. Figure 2 shows the complete view of the fabricated applicator.

\section{Laboratory test of the applicator}

During test, applicator was setup at upper position in such a way that the drive wheel moves easily. Two-third portion of the tank was filled with granule. The drive wheel was rotated for 20 times continuously at normal speed and then the dispensed granules were collected from the bottom of the output

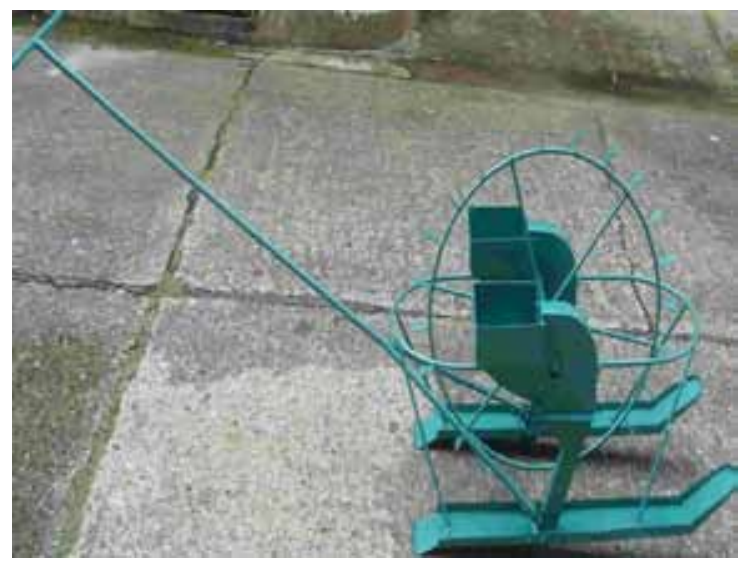

Fig. 2. BRRI USG applicator.

channel. Dispensing efficiency was calculated by counting the number of dispensed granule. In laboratory test conditions, dispensing efficiency was found around $99 \%$. Table 3 presents the result of the laboratory test.

\section{Field test of the applicator}

BRRI USG was operated in BBRI, Gazipur research plot to observe the performance and compare with tradition placement method of USG. During field operation of the applicator, the walking speed of the operator was found $1.95 \mathrm{~km} \mathrm{hr}^{-1}$. Field capacity were about 32.5 decimal $\mathrm{hr}^{-1}$ whereas manual USG 
Table 3. Laboratory test results of the applicator, 2012.

\begin{tabular}{|c|c|c|c|}
\hline No. of trial & $\begin{array}{l}\text { No. of } \\
\text { rotation }\end{array}$ & $\begin{array}{c}\text { No. of } \\
\text { USG } \\
\text { dispensed }\end{array}$ & $\begin{array}{c}\% \text { of } \\
\text { dispensed } \\
\text { USG }\end{array}$ \\
\hline 1 & 20 & 102 & 100 \\
\hline 2 & 20 & 100 & 100 \\
\hline 3 & 20 & 97 & 97 \\
\hline 4 & 20 & 98 & 98 \\
\hline 5 & 20 & 99 & 99 \\
\hline 6 & 20 & 100 & 100 \\
\hline Average & & & 99 \\
\hline
\end{tabular}

Table 4. Field performance of the improved Applicator, 2012.

\begin{tabular}{lcc}
\hline Item & $\begin{array}{c}\text { BRRI USG } \\
\text { applicator }\end{array}$ & $\begin{array}{c}\text { Traditional } \\
\text { application }\end{array}$ \\
\hline Walking speed $\left(\mathrm{km} \mathrm{hr}^{-1}\right)$ & 1.95 & - \\
Field capacity $\left(\mathrm{ha} \mathrm{hr}^{-1}\right)$ & 0.13 & 0.018 \\
$\begin{array}{l}\text { Depth of placement }(\mathrm{cm}) \\
\text { Wt. of dispensed USG }\end{array}$ & $5-6$ & $4-5$ \\
$\left(\mathrm{~kg} \mathrm{ha}^{-1}\right)$ & 165 & 165 \\
\hline
\end{tabular}

application capacity was found 4.5 decimal $\mathrm{hr}^{-1}$. The depth of placement of the granule was 5-6 cm for applicator and $4-5 \mathrm{~cm}$ for manual placing (Table 4).

\section{Amount of dispensed granules}

Fertilizer dose was varied with different adjustments. Normally $168 \mathrm{~kg}$ urea for Boro and $112 \mathrm{~kg}$ urea for Aman season is recommended as USG form. Design rate of USG dispensing in Boro season is 187, 168 and $153 \mathrm{~kg} \mathrm{ha}^{-1}$ for the arrangement of line to line spacing 18, 20 and $22 \mathrm{~cm}$ whereas it is 125, 112 and $102 \mathrm{~kg} \mathrm{ha}^{-1}$ in Aman season (Table 5).

Field trials of USG applicator during Aman 2011 Applicator performance. During field operation of the applicator, the walking speed of the operator was found $3.72 \mathrm{~km} \mathrm{hr}^{-1}$ and field capacity was about 36 decimal hr-1 $\left(0.146\right.$ ha hr$^{-}$ 1) whereas manual USG application capacity was found 4.5 decimal hr-1 $\left(0.018 \mathrm{ha} \mathrm{hr}^{-1}\right)$. The depth of placement of the granule was around $6.32 \mathrm{~cm}$ (Table 6).

Yield performance. There was no significant yield variation observed in different $\mathrm{N}$ fertilization method in studied six locations except Kushtia (Table 7). In Kushtia, yield was significantly higher when $\mathrm{N}$ was applied as USG applying by USG applicator than other treatments. In all the cases, USG gave higher yield than prilled urea. Although there

Table 5. Amount of dispensed granules for three different adjustment of the applicator.

\begin{tabular}{lcccc}
\hline \multirow{2}{*}{ Season } & \multirow{2}{*}{$\begin{array}{c}\text { Recommended } \\
\text { size of granules }(\mathrm{g})\end{array}$} & Spacing $18 \times 20 \mathrm{~cm}$ & Spacing $20 \times 20 \mathrm{~cm}$ & Spacing $22 \times 20 \mathrm{~cm}$ \\
\cline { 3 - 5 } Boro & 2.7 & 187 & 168 & 153 \\
Aman & 1.8 & 125 & 112 & -- \\
\hline
\end{tabular}

Table 6. Field performance of the BRRI USG applicator during Aman 2011.

\begin{tabular}{|c|c|c|c|c|c|c|c|}
\hline \multirow{2}{*}{ Place } & \multirow{2}{*}{$\begin{array}{l}\text { Walking speed } \\
\left(\mathrm{km} \mathrm{hr}^{-1}\right)\end{array}$} & \multicolumn{2}{|c|}{$\begin{array}{l}\text { Field capacity } \\
\left(\text { ha } \mathrm{hr}^{-1}\right)\end{array}$} & \multicolumn{2}{|c|}{$\begin{array}{c}\text { Depth of } \\
\text { of placement }(\mathrm{cm})\end{array}$} & \multicolumn{2}{|c|}{$\begin{array}{l}\text { Wt of dispensed USG } \\
\qquad\left(\mathrm{kg} \mathrm{ha}^{-1}\right)\end{array}$} \\
\hline & & App. & Hand & App. & Hand & App. & Hand \\
\hline BRRI, Gazipur & 3.45 & 0.134 & 0.018 & 6.8 & 5.8 & 118.5 & 112 \\
\hline BRRI RS, Kushtia & 3.95 & 0.157 & 0.015 & 6 & 5.4 & 119.5 & 115.5 \\
\hline BRRI RS, Rajshahi & 3.55 & 0.139 & 0.021 & 6 & 5.9 & 118 & 110 \\
\hline BRRI RS, Rangpur & 3.87 & 0.152 & 0.019 & 6 & 5.5 & 116.7 & 112.5 \\
\hline BRRI RS, Comilla & 3.9 & 0.157 & 0.017 & 6.6 & 5.7 & 119.5 & 116 \\
\hline Netrakona & 3.6 & 0.136 & 0.02 & 6.5 & 6.2 & 120 & 114 \\
\hline Average & 3.72 & 0.146 & 0.018 & 6.32 & 5.75 & 118.7 & 113.33 \\
\hline
\end{tabular}


Table 7. Yield performance of BRRI varieties in different locations as affected by different methods of $\mathrm{N}$ fertilization.

\begin{tabular}{|c|c|c|c|c|c|c|c|c|}
\hline \multirow{3}{*}{ Treat } & \multicolumn{6}{|c|}{ Yield (t ha-1) } & \multicolumn{2}{|c|}{ Av. yield $\left(\mathrm{t} \mathrm{ha}^{-1}\right)$} \\
\hline & $\begin{array}{l}\text { BRRI RS } \\
\text { Kushtia }\end{array}$ & $\begin{array}{l}\text { BRRI RS } \\
\text { Rajshahi }\end{array}$ & $\begin{array}{c}\text { BRRI } \\
\text { Gazipur }\end{array}$ & Netrakona & $\begin{array}{l}\text { BRRI RS } \\
\text { Comilla }\end{array}$ & $\begin{array}{l}\text { BRRI RS } \\
\text { Rangpur }\end{array}$ & BRRI & BRRI \\
\hline & $\begin{array}{c}\text { BRRI } \\
\text { dhan49 }\end{array}$ & $\begin{array}{c}\text { BRRI } \\
\text { dhan49 }\end{array}$ & $\begin{array}{c}\text { BRRI } \\
\text { dhan49 }\end{array}$ & $\begin{array}{c}\text { BRRI } \\
\text { dhan33 }\end{array}$ & $\begin{array}{c}\text { BRRI } \\
\text { dhan49 }\end{array}$ & $\begin{array}{c}\text { BRRI } \\
\text { dhan49 }\end{array}$ & dhan49 & dhan33 \\
\hline $\mathrm{T}_{1}$ & 5.75 & 4.96 & 4.97 & 4.85 & 4.93 & 5.05 & 5.13 & 4.85 \\
\hline $\mathrm{T}_{2}$ & 5.34 & 5.58 & 4.63 & 4.98 & 4.66 & 5.24 & 5.09 & 4.98 \\
\hline $\mathrm{T}_{3}$ & 4.80 & 4.67 & 4.45 & 4.17 & 4.51 & 4.75 & 4.64 & 4.17 \\
\hline$\% \mathrm{CV}$ & 3.5 & 6.6 & 7.2 & 6.6 & 10.5 & 8.5 & - & - \\
\hline $\mathrm{LSD}_{0.05}$ & 0.82 & ns & ns & ns & ns & ns & - & - \\
\hline
\end{tabular}

was no significant difference in studied three treatments but USG gave around $0.5 \mathrm{t} \mathrm{ha}^{-1}$ more yield than prilled urea. It might be due to the USG produced higher effective tiller $\mathrm{m}^{-2}$ as well as higher grains $\mathrm{m}^{-2}$ resulted in higher yield (Tables 8-13).

\section{Yield parameters}

BRRI RS, Kushtia. Tiller number at 55 DAT and at harvest was found statistically similar in both $\mathrm{T}_{1}$ and $\mathrm{T}_{2}$ applying USG by hand and machine respectively whereas it was found significantly less in $\mathrm{T}_{3}$ applying prilled urea by broadcasting method. But plant height was found 105.5, 103.5 and $105.2 \mathrm{~cm}$ for three treatments respectively. Average panicle length was 20.93, 20.32 and $21.42 \mathrm{~cm}$ and grains per panicle were 97, 95 and 98 nos. for $\mathrm{T}_{1}, \mathrm{~T}_{2}$ and $\mathrm{T}_{3}$, respectively. But plant height, grains per panicle and percent of sterility were found statistically identical in all treatments. Number of effective tillers per $\mathrm{m}^{2}$ was 293, 278 and 248 and $1000 \mathrm{~g}$ was 20.35, 20.52 and $20.05 \mathrm{~g}$ for $\mathrm{T}_{1}, \mathrm{~T}_{2}$ and $\mathrm{T}_{3}$, respectively. Number of effective tiller was statistically identical in the both $T_{1}$ and $T_{2}$ whereas it was significantly less in $\mathrm{T}_{3}$. Yield $\left(\mathrm{t} \mathrm{ha}^{-1}\right)$ was found $5.75,5.34$ and 4.80 for $T_{1} T_{2}$ and $T_{3}$ respectively. Yield of $T_{2}$ was statistically similar with $T_{1}$ and $\mathrm{T}_{3}$ was similar with $\mathrm{T}_{2}$. Moreover, yield in $\mathrm{T}_{1}$ was significantly more than $\mathrm{T}_{3}$ (Table 8).

BRRI RS, Rajshahi. Yield and yield contributing parameters for $T_{1}, T_{2}$ and $T_{3}$ were found statistically identical at BRRI RS, Rajshahi. The panicle length was 19.03, 19.40 and $19.13 \mathrm{~cm}$ and grain panicle ${ }^{-1}$ was 96, 96 and 99 for $T_{1}, T_{2}$ and $T_{3}$ respectively. Number of effective tillers per $\mathrm{m}^{2}$ was 261, 295 and 235 and 1000 grain weight was 19.75, 19.55 and 19.68 $\mathrm{g}$ for $\mathrm{T}_{1}, \mathrm{~T}_{2}$ and $\mathrm{T}_{3}$ respectively. Yield ( $\left.\mathrm{t} \mathrm{ha} \mathrm{a}^{-1}\right)$ was found $4.96,5.58$ and 4.67 for $T_{1^{\prime}}, T_{2}$ and $T_{3^{\prime}}$ respectively (Table 9 ).

BRRI HQ, Gazipur. Yield and yield contributing parameters for $T_{1}, T_{2}$ and $T_{3}$ were found statistically identical at BRRI HQ, Gazipur. Average panicle length was 20.13, 20.70 and $20.30 \mathrm{~cm}$ and grains per panicle were 92,96 and 98 for $\mathrm{T}_{1}, \mathrm{~T}_{2}$ and $\mathrm{T}_{3}$, respectively. Number of effective tillers per $\mathrm{m}^{2}$ was 285, 254 and 245 and 1000 grain weight (TGW) was 19.20, 19.14 and $18.80 \mathrm{~g}$ for $\mathrm{T}_{1}, \mathrm{~T}_{2}$ and $\mathrm{T}_{3}$, respectively. Yield ( $\mathrm{t} \mathrm{ha}^{-1}$ ) was found $4.97,4.63$ and 4.45 for $\mathrm{T}_{1}, \mathrm{~T}_{2}$ and $\mathrm{T}_{3}$, respectively (Table 10).

Farmer's field in Netrakona. Tiller number at 25 and 55 DAT was significantly higher in $\mathrm{T}_{2}$ compared to $\mathrm{T}_{3}$. Tiller number of $\mathrm{T}_{2}$ and $\mathrm{T}_{3}$ at 25 and 55 DAT was statistically similar with $\mathrm{T}_{1}$. Tiller number at harvest was found statistically identical in all treatments. Moreover plant height and panicle length was found identical for all the treatments. Grains panicle ${ }^{-1}$ were 109, 111 and 99 for $\mathrm{T}_{1}, \mathrm{~T}_{2}$ and $\mathrm{T}_{3}$ and both of $\mathrm{T}_{1}$ and $\mathrm{T}_{2}$ was significantly higher than $\mathrm{T}_{3}$. Panicles per $\mathrm{m}^{2}$ were found 230, 232 and 217 for $\mathrm{T}_{1}, \mathrm{~T}_{2}$ and $\mathrm{T}_{3}$ and all was statistically identical. Percent of sterility was found significantly higher in $T_{3}$ compared to $T_{1}$ and $\mathrm{T}_{2}$ whereas it was higher in $\mathrm{T}_{1}$ compared to $\mathrm{T}_{2}$. TGW was 19.26, 19.42 and $19.31 \mathrm{~g}$ for $\mathrm{T}_{1}, \mathrm{~T}_{2}$ and $\mathrm{T}_{3}$ respectively. TGW was statistically identical for all treatments. Yield ( $\mathrm{t} \mathrm{ha}^{-1}$ ) was found $4.85,4.98$ and 4.17 for $\mathrm{T}_{1}, \mathrm{~T}_{2}$ and $\mathrm{T}_{3}$ respectively which was statistically identical (Table 11). 
Table 8. Performance of yield and yield contributing parameters, BRRI RS, Kushtia.

\begin{tabular}{|c|c|c|c|c|c|c|c|c|c|c|}
\hline \multirow[b]{2}{*}{ Treat. } & \multicolumn{3}{|c|}{ No. of tillers per $\mathrm{m}^{2}$ at } & \multirow[b]{2}{*}{$\begin{array}{l}\text { Plant height } \\
(\mathrm{cm})\end{array}$} & \multirow{2}{*}{$\begin{array}{l}\text { Panicle } \\
\text { length } \\
(\mathrm{cm})\end{array}$} & \multirow{2}{*}{$\begin{array}{c}\text { Grain } \\
\text { per } \\
\text { panicle }\end{array}$} & \multirow{2}{*}{$\begin{array}{l}\text { No. of } \\
\text { effective } \\
\text { tillers } \\
\text { per } \mathrm{m}^{2}\end{array}$} & \multirow[b]{2}{*}{$\begin{array}{l}\text { Sterility } \\
(\%)\end{array}$} & \multirow{2}{*}{$\begin{array}{c}\text { TGW } \\
\text { at } 14 \% \\
\text { m.c. } \\
\text { (g) }\end{array}$} & \multirow{2}{*}{$\begin{array}{c}\text { Yield at } \\
14 \% \text { m.c. } \\
\left(\mathrm{t} \mathrm{ha}^{-1}\right)\end{array}$} \\
\hline & $25 \mathrm{DAT}$ & $\begin{array}{c}55 \\
\text { DAT }\end{array}$ & harvest & & & & & & & \\
\hline $\mathrm{T}_{1}$ & 318 & 399 & 366 & 105.5 & 20.93 & 97 & 293 & 19.85 & 20.35 & 5.750 \\
\hline $\mathrm{T}_{2}$ & 278 & 362 & 341 & 103.5 & 20.32 & 95 & 278 & 16.55 & 20.52 & 5.343 \\
\hline $\mathrm{T}_{3}$ & 232 & 320 & 308 & 105.2 & 21.43 & 98 & 248 & 17.56 & 20.05 & 4.803 \\
\hline$\% \mathrm{CV}$ & 5.96 & 5.24 & 3.90 & 1.02 & 4.50 & 3.70 & 3.68 & 16.85 & 0.55 & 4.97 \\
\hline $\mathrm{LSD}_{0.05}$ & ns & 42.74 & 29.91 & ns & ns & ns & 22.74 & ns & ns & 0.59 \\
\hline
\end{tabular}

Table 9. Performance of yield and yield contributing parameters, BRRI RS, Rajshahi.

\begin{tabular}{ccccccccccc}
\hline & \multicolumn{2}{c}{ No. of tillers per $\mathrm{m}^{2}$ at } & Plant & Panicle \\
Treat. & 25 DAT & 55 DAT & harvest & $\begin{array}{c}\text { Grain } \\
(\mathrm{cm})\end{array}$ & $\begin{array}{c}\text { No. of } \\
\text { length } \\
(\mathrm{cm})\end{array}$ & $\begin{array}{c}\text { per } \\
\text { panicle }\end{array}$ & $\begin{array}{c}\text { tillers } \\
\text { per } \mathrm{m}^{2}\end{array}$ & $\begin{array}{c}\text { Sterility } \\
(\%)\end{array}$ & $\begin{array}{c}\text { TGW at } \\
14 \% \text { m.c. } \\
(\mathrm{g})\end{array}$ & $\begin{array}{c}\text { Yield at } \\
14 \% \text { m.c. } \\
\left.(\mathrm{t} \mathrm{ha})^{-1}\right)\end{array}$ \\
\hline $\mathrm{T}_{1}$ & 248 & 387 & 362 & 103.0 & 19.03 & 96 & 261 & 10.13 & 19.75 \\
$\mathrm{~T}_{2}$ & 249 & 400 & 388 & 103.3 & 19.40 & 96 & 295 & 12.97 & 19.55 & 5.96 \\
$\mathrm{~T}_{3}$ & 226 & 346 & 329 & 101.9 & 19.13 & 99 & 235 & 12.63 & 19.68 & 4.67 \\
$\% \mathrm{CV}$ & 7.54 & 8.33 & 7.11 & 1.02 & 4.55 & 9.27 & 9.95 & 29.30 & 1.83 & 15.73 \\
$\mathrm{LSD}_{0.05}$ & $\mathrm{~ns}$ & $\mathrm{~ns}$ & $\mathrm{~ns}$ & $\mathrm{~ns}$ & $\mathrm{~ns}$ & $\mathrm{~ns}$ & $\mathrm{~ns}$ & $\mathrm{~ns}$ & $\mathrm{~ns}$ & $\mathrm{~ns}$ \\
\hline
\end{tabular}

Table 10. Performance of yield and yield contributing parameters, BRRI HQ, Gazipur.

\begin{tabular}{|c|c|c|c|c|c|c|c|c|c|c|}
\hline \multirow[b]{2}{*}{ Treat. } & \multicolumn{3}{|c|}{ No. of tillers per $\mathrm{m}^{2}$ at } & \multirow{2}{*}{$\begin{array}{l}\text { Plant } \\
\text { height } \\
(\mathrm{cm})\end{array}$} & \multirow{2}{*}{$\begin{array}{c}\text { Panicle } \\
\text { length } \\
(\mathrm{cm})\end{array}$} & \multirow{2}{*}{$\begin{array}{l}\text { Grain } \\
\text { per } \\
\text { panicle }\end{array}$} & \multirow{2}{*}{$\begin{array}{l}\text { No. of } \\
\text { effective } \\
\text { tillers } \\
\text { per } \mathrm{m}^{2}\end{array}$} & \multirow{2}{*}{$\begin{array}{l}\text { Sterility } \\
(\%)\end{array}$} & \multirow{2}{*}{$\begin{array}{c}\text { TGW at } \\
14 \% \\
\text { m.c. (g) }\end{array}$} & \multirow{2}{*}{$\begin{array}{l}\text { Yield at } \\
14 \% \text { m.c. } \\
\left(\mathrm{t} \mathrm{ha}^{-1}\right)\end{array}$} \\
\hline & $25 \mathrm{DAT}$ & $55 \mathrm{DAT}$ & harvest & & & & & & & \\
\hline $\mathrm{T}_{1}$ & 256 & 346 & 334 & 97.97 & 20.13 & 92 & 285 & 9.970 & 19.20 & 4.973 \\
\hline $\mathrm{T}_{2}$ & 260 & 328 & 311 & 98.27 & 20.70 & 96 & 254 & 12.59 & 19.14 & 4.633 \\
\hline $\mathrm{T}_{3}$ & 241 & 309 & 296 & 96.80 & 20.30 & 98 & 245 & 9.793 & 18.80 & 4.450 \\
\hline$\% \mathrm{CV}$ & 14.11 & 9.60 & 8.72 & 2.91 & 4.62 & 11.29 & 11.26 & 32.23 & 2.00 & 9.42 \\
\hline $\mathrm{LSD}_{0.05}$ & ns & ns & ns & ns & ns & ns & ns & ns & ns & ns \\
\hline
\end{tabular}

Table 11. Performance of yield and yield contributing parameters, farmer's field at Netrakona.

\begin{tabular}{|c|c|c|c|c|c|c|c|c|c|c|}
\hline \multirow[b]{2}{*}{ Treat. } & \multicolumn{3}{|c|}{ No. of tillers per $\mathrm{m}^{2}$ at } & \multirow{2}{*}{$\begin{array}{l}\text { Plant } \\
\text { height } \\
(\mathrm{cm})\end{array}$} & \multirow{2}{*}{$\begin{array}{c}\text { Panicle } \\
\text { length } \\
(\mathrm{cm})\end{array}$} & \multirow{2}{*}{$\begin{array}{c}\text { Grain } \\
\text { per } \\
\text { panicle }\end{array}$} & \multirow{2}{*}{$\begin{array}{l}\text { No. of } \\
\text { effective } \\
\text { tillers } \\
\text { per } \mathrm{m}^{2}\end{array}$} & \multirow{2}{*}{$\begin{array}{c}\text { Sterility } \\
(\%)\end{array}$} & \multirow{2}{*}{$\begin{array}{c}\text { TGW } \\
\text { at } 14 \% \\
\text { m.c. (g) }\end{array}$} & \multirow{2}{*}{$\begin{array}{l}\text { Yield at } \\
14 \% \text { m.c. } \\
\left(\mathrm{t} \mathrm{ha}^{-1}\right)\end{array}$} \\
\hline & $25 \mathrm{DAT}$ & $\begin{array}{c}55 \\
\text { DAT }\end{array}$ & harvest & & & & & & & \\
\hline $\mathrm{T}_{1}$ & 220 & 291 & 279 & 106.7 & 23.07 & 109 & 230 & 16.15 & 19.26 & 4.85 \\
\hline $\mathrm{T}_{2}$ & 231 & 298 & 283 & 101.4 & 23.37 & 111 & 232 & 13.92 & 19.42 & 4.98 \\
\hline $\mathrm{T}_{3}$ & 212 & 274 & 274 & 101.2 & 21.83 & 99 & 217 & 18.57 & 19.31 & 4.17 \\
\hline$\% \mathrm{CV}$ & 2.84 & 2.76 & 4.06 & 9.12 & 5.77 & 2.65 & 6.24 & 5.45 & 3.19 & 9.53 \\
\hline $\mathrm{LSD}_{0.05}$ & 14.3 & 17.9 & ns & ns & ns & 6.4 & ns & 2.0 & ns & ns \\
\hline
\end{tabular}


BRRI RS, Comilla. Yield and yield contributing parameters for $T_{1}, T_{2}$ and $T_{3}$ was found statistically identical at BRRI RS, Comilla except grains per panicle. Average panicle length was 21.17, 20.40 and $20.13 \mathrm{~cm}$ and grains per panicle were 88,86 and 42 for $\mathrm{T}_{1}, \mathrm{~T}_{2}$ and $\mathrm{T}_{3}$, respectively. Grain panicle ${ }^{-1}$ was significantly higher in $T_{1}$ compared to $T_{3}$ and statistically similar with $T_{2}$ whereas $T_{3}$ also statistically similar with $\mathrm{T}_{2}$. Number of effective tillers per $\mathrm{m}^{2}$ was 299, 297 and 297 and TGW was 19.33, 19.03 and $19.32 \mathrm{~g}$ for $\mathrm{T}_{1} \mathrm{~T}_{2}$ and $\mathrm{T}_{3}$ respectively, which was statistically identical in all treatments. Yield $\left(\mathrm{t} \mathrm{ha}^{-1}\right)$ was found 4.927, 4.657 and 4.510 for $\mathrm{T}_{1}, \mathrm{~T}_{2}$ and $\mathrm{T}_{3}$ respectively (Table 12).

BRRI RS, Rangpur. Yield and yield contributing parameters for $\mathrm{T}_{1}, \mathrm{~T}_{2}$ and $\mathrm{T}_{3}$ was found statistically identical at BRRI RS, Rangpur. Average panicle length was 20.17, 18.63 and $19.67 \mathrm{~cm}$ and grains per panicle was 96, 97 and 106 for $\mathrm{T}_{1}, \mathrm{~T}_{2}$ and $\mathrm{T}_{3}$, respectively. Number of effective tillers per $\mathrm{m}^{2}$ was 273,286 and 244 and TGW was 19.50, 19.34 and 18.77 $\mathrm{g}$ for $\mathrm{T}_{1} \mathrm{~T}_{2}$ and $\mathrm{T}_{3}$, respectively. Yield ( $\left.\mathrm{t} \mathrm{ha} \mathrm{a}^{-1}\right)$ was found 5.05, 5.24 and 4.75 for $\mathrm{T}_{1}, \mathrm{~T}_{2}$ and $\mathrm{T}_{3}$ respectively (Table 13).

\section{Field trials of USG applicator in Boro 2012} Applicator performance. BRRI USG was operated in different 11 locations of the country to evaluate the field performance of the applicator. During field operation of the applicator average walking speed of the operator was found $2.46 \mathrm{~km} \mathrm{hr}^{-1}$ and average field capacity was 32.97 decimal $\mathrm{hr}^{-1}$ whereas manual USG application capacity was found 4.94 decimal $\mathrm{hr}^{-1}$. Average depth of placement of the granule was around $6.01 \mathrm{~cm}$ (Table 14). Average $162 \mathrm{~kg}$ of USG fertilizer was dispensed per hectare during applicator operation whereas $169.25 \mathrm{~kg}$ of USG fertilizer for hand application.

Yield performance. There were significant yield variation observed in different $\mathrm{N}$ fertilization method in studied locations

Table 12. Performance of yield and yield contributing parameters, BRRI RS, Comilla.

\begin{tabular}{lcccccccccc}
\hline Treat. & \multicolumn{2}{c}{ No. of tillers per $\mathrm{m}^{2}$ at } & $\begin{array}{c}\text { Plant } \\
\text { height } \\
(\mathrm{cm})\end{array}$ & $\begin{array}{c}\text { Panicle } \\
\text { length } \\
(\mathrm{cm})\end{array}$ & $\begin{array}{c}\text { Grain } \\
\text { per } \\
\text { panicle }\end{array}$ & $\begin{array}{c}\text { No. of } \\
\text { effective } \\
\text { tillers } \\
\text { per } \mathrm{m}^{2}\end{array}$ & $\begin{array}{c}\text { Sterility } \\
(\%)\end{array}$ & $\begin{array}{c}\text { TGW at } \\
14 \% \text { m.c. } \\
(\mathrm{g})\end{array}$ & $\begin{array}{c}\text { Yield at } \\
14 \% \text { m.c. } \\
\left(\mathrm{t} \mathrm{ha}^{-1}\right)\end{array}$ \\
\hline $\mathrm{T}_{1}$ & 250 & 349 & 322 & 99.63 & 21.17 & 88 & 299 & 14.67 & 19.33 & 4.927 \\
$\mathrm{~T}_{2}$ & 244 & 352 & 320 & 100.1 & 20.40 & 86 & 297 & 13.33 & 19.03 & 4.657 \\
$\mathrm{~T}_{3}$ & 238 & 343 & 317 & 95.54 & 20.13 & 82 & 297 & 16.00 & 19.32 & 4.510 \\
$\% \mathrm{CV}$ & 2.90 & 4.02 & 1.57 & 2.37 & 3.16 & 2.98 & 2.41 & 7.87 & 1.35 & 5.48 \\
$\mathrm{LSD}_{0.05}$ & $\mathrm{~ns}$ & $\mathrm{~ns}$ & $\mathrm{~ns}$ & $\mathrm{~ns}$ & $\mathrm{~ns}$ & 5.8 & $\mathrm{~ns}$ & $\mathrm{~ns}$ & $\mathrm{~ns}$ & $\mathrm{~ns}$ \\
\hline
\end{tabular}

Table 13. Performance of yield and yield contributing parameters, BRRI RS, Rangpur.

\begin{tabular}{|c|c|c|c|c|c|c|c|c|c|c|}
\hline \multirow{2}{*}{ Treat. } & \multicolumn{3}{|c|}{ No. of tillers per $\mathrm{m}^{2}$ at } & \multirow{2}{*}{$\begin{array}{l}\text { Plant } \\
\text { height } \\
(\mathrm{cm})\end{array}$} & \multirow{2}{*}{$\begin{array}{l}\text { Panicle } \\
\text { length } \\
(\mathrm{cm})\end{array}$} & \multirow{2}{*}{$\begin{array}{l}\text { Grain } \\
\text { per } \\
\text { panicle }\end{array}$} & \multirow{2}{*}{$\begin{array}{l}\text { No. of } \\
\text { effective } \\
\text { tillers } \\
\mathrm{m}^{-2}\end{array}$} & \multirow{2}{*}{$\begin{array}{l}\text { Sterility } \\
(\%)\end{array}$} & \multirow{2}{*}{$\begin{array}{c}1000 \text { grains } \\
\text { weight } \\
\text { at } 14 \% \\
\text { m.c. }(\mathrm{g})\end{array}$} & \multirow{2}{*}{$\begin{array}{c}\text { Yield at } \\
14 \% \text { m.c. } \\
(\mathrm{t} \mathrm{ha-1})\end{array}$} \\
\hline & $25 \mathrm{DAT}$ & $55 \mathrm{DAT}$ & harvest & & & & & & & \\
\hline $\mathrm{T}_{1}$ & 244 & 313 & 303 & 87.73 & 20.2 & 96 & 273 & 14.61 & 19.50 & 5.05 \\
\hline $\mathrm{T}_{2}$ & 257 & 308 & 290 & 82.60 & 18.6 & 97 & 286 & 16.02 & 19.34 & 5.24 \\
\hline $\mathrm{T}_{3}$ & 242 & 293 & 286 & 84.27 & 9.7 & 106 & 244 & 3.33 & 18.77 & 4.75 \\
\hline$\% \mathrm{CV}$ & 2.97 & 3.24 & 3.80 & 5.96 & 2.9 & 7.01 & 8.31 & 10.87 & 0.91 & 7.60 \\
\hline $\mathrm{LSD}_{0.05}$ & ns & ns & ns & ns & 1.3 & ns & ns & ns & 0.40 & ns \\
\hline
\end{tabular}


Table 14. Field performance of the BRRI USG applicator operated in different places during Boro 2012.

\begin{tabular}{|c|c|c|c|c|c|c|c|c|c|c|c|}
\hline \multirow[t]{2}{*}{ Place } & \multicolumn{2}{|c|}{$\begin{array}{l}\text { Time of } \\
\text { operation }{ }^{1} \\
\text { (min) }\end{array}$} & \multicolumn{2}{|c|}{$\begin{array}{c}\text { Area } \\
\text { (decimal) }\end{array}$} & \multirow{2}{*}{$\frac{\begin{array}{c}\text { Walking } \\
\text { speed } \\
\left(\mathrm{km} \mathrm{hr}^{-1}\right)\end{array}}{\text { App }}$} & \multicolumn{2}{|c|}{$\begin{array}{l}\text { Field capacity } \\
\quad\left(\mathrm{ha} \mathrm{hr}^{-1}\right)\end{array}$} & \multicolumn{2}{|c|}{$\begin{array}{c}\text { Depth of } \\
\text { of placement } \\
(\mathrm{cm})\end{array}$} & \multicolumn{2}{|c|}{$\begin{array}{c}\text { Wt. of dispensed } \\
\text { USG } \\
\left(\mathrm{Kg} \mathrm{ha}^{-1}\right)\end{array}$} \\
\hline & App & Hand & App & Hand & & App & Hand & App & Hand & App & Hand \\
\hline Kushtia & 65 & 418 & 35 & 35 & 2.4 & 0.13 & 0.02 & 6.0 & 5.5 & 165.0 & 169.0 \\
\hline Kumarkhali & 62 & 265 & 30 & 20 & 2.2 & 0.12 & 0.02 & 5.9 & 5.2 & 169.0 & 172.0 \\
\hline Habiganj & 47 & 114 & 25 & 10 & 2.8 & 0.13 & 0.02 & 5.8 & 5.8 & 162.0 & 169.0 \\
\hline Baniachang & 48 & 53 & 25 & 5 & 2.8 & 0.13 & 0.02 & 6.0 & 5.8 & 158.0 & 165.0 \\
\hline BRRI, Habiganj & 26 & 51 & 16 & 4 & 2.2 & 0.15 & 0.02 & 6.2 & 6.0 & 162.0 & 167.0 \\
\hline Burhichang & 50 & 42 & 25 & 5 & 2.5 & 0.12 & 0.03 & 6.0 & 5.5 & 160.0 & 169.0 \\
\hline Laksam & 51 & 49 & 25 & 5 & 2.2 & 0.12 & 0.02 & 6.2 & 5.6 & 162.0 & 169.0 \\
\hline Rangpur & 50 & 50 & 25 & 5 & 2.9 & 0.12 & 0.02 & 5.9 & 5.1 & 156.0 & 172.0 \\
\hline Netrakona & 46 & 49 & 25 & 5 & 2.3 & 0.13 & 0.02 & 6.1 & 5.4 & 160.0 & 170.0 \\
\hline Purbadhala & 47 & 51 & 25 & 5 & 2.2 & 0.13 & 0.02 & 6.2 & 6.0 & 162.0 & 168.0 \\
\hline Rajshahi & 36 & 92 & 20 & 8 & 2.3 & 0.13 & 0.02 & 6.0 & 6.0 & 165.0 & 170.0 \\
\hline \multicolumn{5}{|c|}{ Average } & 2.46 & 0.13 & 0.02 & 6.01 & 5.61 & 162 & 169.25 \\
\hline
\end{tabular}

except BRRI RS, Habiganj; Burhichang, Akkelpur, Rangpur (Table 15). In kushtia (Sadar and Khumarkhali), Habiganj (Sadar and Baniachang), Laksam, Comilla; Netrakona (Sadar and Purbadhala) and Paba, Rajshahi, yield was significantly higher when $\mathrm{N}$ was applied as USG using both traditional method and USG applicator than prilled urea. In all the cases, USG gave higher yield than prilled urea. Although the performance of USG applied by USG applicator and hand was not consistent. In some locations, hand applied USG gave higher yield than applicator applied USG or vice versa. Considering the average yield of 12 locations; USG gave around $0.75 \mathrm{t} \mathrm{ha}^{-1}$ more yield than prilled urea. It might be due to the
USG produced higher effective tiller $\mathrm{m}^{2}$ as well as higher grains per $\mathrm{m}^{2}$ resulted of higher yield.

\section{DISCUSSION}

Urea fertilizer is one of the most essential chemical fertilizers for growing rice all over the world (Prashad et al., 1979). The urea application method in the rice fields depends on the types of urea fertilizer. In Bangladesh, USG applicators are being developed and improved by BRRI, Bangladesh Agricultural Research Institute (BARI) and International Fertilizer Development Center (IFDC) (Kshirode, 2010). BRRI developed USG

Table 15. Yield performance of BRRI varieties in different locations as affected by different methods of $\mathrm{N}$ fertilization.

\begin{tabular}{|c|c|c|c|c|c|c|c|c|c|c|c|c|}
\hline \multirow[b]{2}{*}{ Treat } & \multicolumn{11}{|c|}{ Yield $(\mathrm{t} \mathrm{ha-1})$} & \multirow{2}{*}{$\begin{array}{l}\text { Av. yield } \\
\left(\mathrm{t} \mathrm{ha}^{-1}\right)\end{array}$} \\
\hline & $\begin{array}{l}\text { Sadar, } \\
\text { Kushtia }\end{array}$ & $\begin{array}{l}\text { Kumar., } \\
\text { Kushtia }\end{array}$ & $\begin{array}{l}\text { Sadar, } \\
\text { Habi. }\end{array}$ & $\begin{array}{l}\text { Bania- } \\
\text { chang }\end{array}$ & $\begin{array}{l}\text { BRRI } \\
\text { Habi }\end{array}$ & Burirchang & Laksam & $\begin{array}{l}\text { Sadar, } \\
\text { Rang. }\end{array}$ & Netrakona & Purbadhala & $\begin{array}{l}\text { Paba } \\
\text { Raj. }\end{array}$ & \\
\hline $\mathrm{T}_{1}$ & 8.50 & 9.96 & 7.68 & 7.97 & 8.08 & 8.25 & 7.58 & 6.83 & 7.52 & 7.33 & 8.56 & 8.02 \\
\hline $\mathrm{T}_{2}$ & 8.62 & 10.2 & 7.94 & 8.22 & 8.28 & 8.23 & 7.71 & 6.55 & 7.59 & 7.47 & 8.60 & 8.13 \\
\hline $\mathrm{T}_{3}$ & 8.03 & 9.38 & 6.82 & 6.63 & 8.11 & 7.79 & 6.44 & 6.20 & 6.64 & 6.64 & 7.99 & 7.33 \\
\hline$\% \mathrm{CV}$ & 0.99 & 2.10 & 0.81 & 2.65 & 3.61 & 3.08 & 4.01 & 4.42 & 2.76 & 3.04 & 2.14 & - \\
\hline $\mathrm{LSD}_{0.05}$ & 0.45 & 0.52 & 0.22 & 1.25 & ns & ns & 0.92 & ns & 0.74 & & 0.38 & - \\
\hline
\end{tabular}

Note: Kumar=Kumarkhali, Habi=Habiganj, Rang=Rangpur, Raj=Rasjshahi 
applicator was used to apply USG in nonoxidized zone at $6-10 \mathrm{~cm}$ depth from surface at desired spacing to maintain the recommended USG fertilizer doses of 118 and $168 \mathrm{~kg} \mathrm{ha}^{-1}$ during Aman and Boro season respectively (Hossen et al., 2013). Recommended dose of fertilizer could be applied only maintaining the standard line to line spacing $20 \mathrm{~cm}$. There are possibilities of under and over dose of fertilizer for 18 and $22 \mathrm{~cm}$ adjustment of the applicator, respectively. Therefore, it is recommended to use the applicator for standard $20 \mathrm{~cm}$ line to line spacing. However, $20 \times 20 \mathrm{~cm}$ line to line spacing gave higher grain yield (Das et al., 2013). In laboratory condition, dispensing percentage was observed about $99 \%$. The capacity of BRRI model was high, but breakage percentage was more than 10\% (Ahamed et al., 2014).

Field performance of any wetland machine depends on machine maneuverability, field pattern, shape and size, soil condition and system limitation (Hunt, 1995). Field capacity of BRRI USG applicator also varied soil to soil, season to season and research field to farmers' field. Walking speed directly influenced the field capacity of the applicator. Walking speed during field operation of the applicator was observed $1.95 \mathrm{~km} \mathrm{hr}^{-1}$ in research field Gazipur whereas average walking speed of operation in different locations and different soil conditions was 3.72 and $2.46 \mathrm{~km} \mathrm{hr}^{-1}$ in Aman and Boro season, respectively. Clay muddy soil without ploughpan hindered the walking speed during operation in Gazipur. However, optimum softness and depth of plough in Aman season due to prolonged submergence of soil by rain water influenced the field operation of the applicator resulting more walking speed. Contrary to, insufficient depth of plough in Boro season reduced the walking speed of the applicator operation.

Depth of USG placement and proper covering improve the efficiency of USG application. Effect of depth USG in depth placing significantly influenced the grain yield as well as yield contributing parameters (Das et al., 2013) and 5 to $10 \mathrm{~cm}$ depth of placement was found optimum for higher grain yield
(Jing Xiang et al., 2013). In this study, it was observed that the average depth of placement of mechanical application varied from 6.01 to $6.32 \mathrm{~cm}$ in Aman and Boro seasons whereas it was less in manual application: 5.61 to $5.75 \mathrm{~cm}$. Depth of placement was apparently more in Aman season compared to that of the Boro season in both mechanical and manual application.

The yield performance of USG was applied by USG applicator or by hand was not consistent. In all locations during both the seasons, grain yield was identical of USG plots either applied by hand or machine. However, in some cases, USG gave significantly higher grain yield compared to prilled urea applied by hand broadcasting method. Although there was no significant difference found in some studied areas, USG gave around $0.5 \mathrm{t} \mathrm{ha}^{-1}$ and $0.75 \mathrm{t} \mathrm{ha}^{-1}$ higher grain yields than prilled urea. It might be due to the USG produced higher effective tillers per $\mathrm{m}^{2}$ as well as higher grains $\mathrm{m}^{2}$ resulted in higher yield. The result is coincided with the findings Bandaogo et al. (2014). However, Bhuiyan et al., 1988 and Mohonty et al., 1990 noticed that the deep placement of USG gave significantly higher grain yield of rice than split application of prilled urea. Islam et al. (2015) observed in two locations that the deep placement of USG and prilled urea by USG applicator (4.91 $\mathrm{t} \mathrm{ha}^{-1}$ ) and prilled urea applicator $\left(4.84 \mathrm{tha}^{-1}\right)$, respectively gave higher grain yield compared to the hand broadcasting of prilled urea fertilizer $\left(4.67 \mathrm{t} \mathrm{ha}^{-1}\right)$ while both the applicators saved $30 \%$ of urea fertilizer.

\section{CONCLUSION}

BRRI USG applicator was found suitable as proper placing of urea briquette fertilizer and labour saving technology in both the Boro and Aman seasons. The operation of USG applicator is easier and has less drudgeries. Response of deep placement of USG fertilizer was more in Boro season compared to Aman season. The yield performance of USG applied by USG applicator or by hand was significantly 
higher compared to prilled urea applied by hand broadcasting method whenever there was no difference between hand and manual application of USG on grain yield and yield contributing parameters.

\section{REFERENCES}

Bandaogo, A, F Bidjokazo, S Youl, E Safo, R Abaidoo and O Andrews. 2014. Effect of fertilizer deep placement with urea supergranule on nitrogen use efficiency of irrigated rice in Sourou Valley (Burkina Faso), Nutr. Cycl. Agroecosyst. DOI 10.1007/s10705-014-9653-6.

Ahamed, M S, A T M Ziauddinand R I Sarker. 2014. Design of improved urea super granule applicator, Int. J. Appl. Sci. and Eng. Res., Vol. 3, Issue 1, www. ijaser.com.

AIS. 2008. Krishi Diary, Agricultural Information Service, Department of Agricultural Extension. Dhaka.

BBS. 2015. Yearbook of Agriculture statistic of Bangladesh. Bangladesh Bureau of Statistics, statistics.

Bhuiyan, N I, A L Shah, M A Saleque and S K Zaman. 1988. Effect of $\mathrm{N}$ source and application method on dry season irrigated rice. IRRN 13(3): 28

Bhuiyn, N I, M A M Miah and M Ishaque. 1998. Research on USG: Findings and Future Research Areas and Recommendations. Paper presented at the national workshop on urea super granule technology (USG), held at BARC, Dhaka, Bangladesh, 25 June 1998.

Craswell, E T and P L G Vlek. 1979. Fate of fertilizer nitrogen applied to wetland rice. International Rice Research Institute. Nitrogen and rice. Los Banos, Laguna, Philippines.

Das, D, A K Chaki, A R Sarker, S Mondal, M M R Sarker and M Moniruzzaman. 2013. Effect of spacing of transplanting, rate and depth of placemnt of urea super granules on the yield of Boro rice. Bull. Inst. Trop. Agr. Kyushu Uni. 36: 85-94, 2013
Datta, De S K. 1978. Fertilizer management for efficient use in wetland rice soils. International Rice Research Institute. Soils and Rice. Los Banos Laguna, Philippines. Division, Ministry of Planning, Government of the People's Republic of Bangladesh.

Hossen, M A, M S Islam, M A Rahman, M D Huda, M G K Bhuyain and B C Nath. 2013. Design and development of a manually operated urea supper granule (USG) applicator. Published in the Journal of Agricultural mechanization in Asia, Africa and Latin America (AMMA), Volume: no. 2, Spring 2013.

Hossen, M A, M A Rahman, M G K Bhuyain, T K Sarkar and M A Alam. 2013. Improvement of BRRI USG applicator. J. Agril. Mach. Bioresour, Eng. 6(1 \& 2) : 33-39.

Huda, F A and M A Khan. 2014. Policy Instruments for Reducing Nitrogen Fertilizer Based Emission: Under Policy Conflict of Self Sufficiency of Food versus Sustainable Management of Agriculture, Huda F A et al., J. Earth Sci. Clim. Change. 5:6.

Hunt, D. 1973. Farm Power and Machinery Management ( $9^{\text {th }}$ edition), Laboratory manual and work book. Seventh edition, Iowa State University Press, Ames, Iowa.

Islam, A K M S, M A Rahman, A K M L Rahman, M T Islam and M I Rahman. 2015. Field performance evaluation of push type prilled urea applicator in rice cultivation. Bangladesh Rice J. 19 (2): 71-81.

Jing, X, V, R Haden, S Peng, B A M Bouman, J Huang, K Cui, R M Visperas, D Zhu, Y Zhang, H Chen. 2013. Effect of deep placement of nitrogen fertilizer on growth, yield, and nitrogen uptake of aerobic rice, AJCS 7(6): 870-877 ISSN: 1835-2707.

Kshirode, C R. 2010. Urea Super Granule, a fertilizer of hope, eco-friendly, economical, promises higher yields with lesser amount. The Daily Star (newspaper), Bangladesh.

Mohaonty, S K, U Singh, V Balasubramanian and K P Jha. 1999. Nitrogen deep-placementtechnologies for productivity, profitability, and environmental quality of rainfed lowland rice systems. Nutr. cycl. Agroecosyst. 53: 43-57.

Savant, N K, PS Ongkingco, F D Garcia, SS Dhane, R R Khadse, S A Chavan and KS Rao. 1992. Agronomic performance of urea briquette applicator in transplanted rice. Nutr. Cycl. Agroecosyst. 32(2): 139-142. 
